\title{
Early Perceptions of COVID-19 Contact Tracing Apps in German-Speaking Countries: Comparative Mixed Methods Study
}

Bettina Maria Zimmermann ${ }^{1,2}$, Dr phil des; Amelia Fiske ${ }^{1}$, PhD; Barbara Prainsack ${ }^{3}$, Prof Dr; Nora Hangel ${ }^{1}$, PhD; Stuart McLennan ${ }^{1,2^{*}}, \mathrm{PhD}$; Alena Buyx ${ }^{1 *}, \mathrm{MD}, \mathrm{PhD}$

\footnotetext{
${ }^{1}$ Institute of History and Ethics in Medicine, Technical University Munich, Munich, Germany

${ }^{2}$ Institute for Biomedical Ethics, University of Basel, Basel, Switzerland

${ }^{3}$ Department of Political Science, University of Vienna, Vienna, Austria

* these authors contributed equally
}

Corresponding Author:

Bettina Maria Zimmermann, Dr phil des

Institute of History and Ethics in Medicine

Technical University Munich

Ismaninger Straße 22

Munich,

Germany

Phone: 498941404042

Email: bettina.zimmermann@tum.de

\section{Abstract}

Background: The main German-speaking countries (Germany, Austria, and Switzerland) have implemented digital contact tracing apps to assist the authorities with COVID-19 containment strategies. Low user rates for these apps can affect contact tracing and, thus, its usefulness in controlling the spread of the novel coronavirus.

Objective: This study aimed to assess the early perceptions of people living in the German-speaking countries and compare them with the frames portrayed in the newspapers during the first wave of the COVID-19 pandemic.

Methods: We conducted qualitative interviews with 159 participants of the SolPan project. Of those, 110 participants discussed contact tracing apps and were included in this study. We analyzed articles regarding contact tracing apps from 12 newspapers in the German-speaking countries.

Results: Study participants perceived and newspaper coverage in all German-speaking countries framed contact tracing apps as governmental surveillance tools and embedded them in a broader context of technological surveillance. Participants identified trust in authorities, respect of individual privacy, voluntariness, and temporary use of contact tracing apps as prerequisites for democratic compatibility. Newspapers commonly referenced the use of such apps in Asian countries, emphasizing the differences in privacy regulation among these countries.

Conclusions: The uptake of digital contact tracing apps in German-speaking countries may be undermined due to privacy risks that are not compensated by potential benefits and are rooted in a deeper skepticism towards digital tools. When authorities plan to implement new digital tools and practices in the future, they should be very transparent and proactive in communicating their objectives and the role of the technology—and how it differs from other, possibly similar, tools. It is also important to publicly address ethical, legal, and social issues related to such technologies prior to their launch.

(J Med Internet Res 2021;23(2):e25525) doi: 10.2196/25525

\section{KEYWORDS}

COVID-19; contact tracing; app; interview study; newspaper content analysis; privacy paradox; digital surveillance; trust; content analysis; surveillance; privacy; interview 


\section{Introduction}

During the COVID-19 pandemic, several country-specific contact tracing apps were introduced to assist and supplement analog contact-tracing. In Austria, Red Cross launched the Stopp Corona app on March 25, 2020; Germany launched the Corona-Warn-App on June 16, 2020; and Switzerland launched the SwissCovid app on June 25, 2020 (Figure 1). All these free apps use Bluetooth Low Energy technology to measure the distance and the duration of contact between smartphones that have the app installed. If the tracking function is enabled, random encrypted codes are automatically exchanged and directly saved on the devices whenever a person encounters another user. These random codes do not reveal any names or identities of people or exact locations, and the codes are erased from the smartphones after 14 days. If a person using the app tests positive for COVID-19, they can voluntarily choose to make their random codes anonymously available so that other users who may have come into contact with the infected person can be notified and asked to contact their local health authorities for further instructions.

Figure 1. Comparative timeline of COVID-19-related restrictions and contact tracing smartphone apps released from March to June 2020. Black: lockdown period; grey: step-wise easing of restrictions.

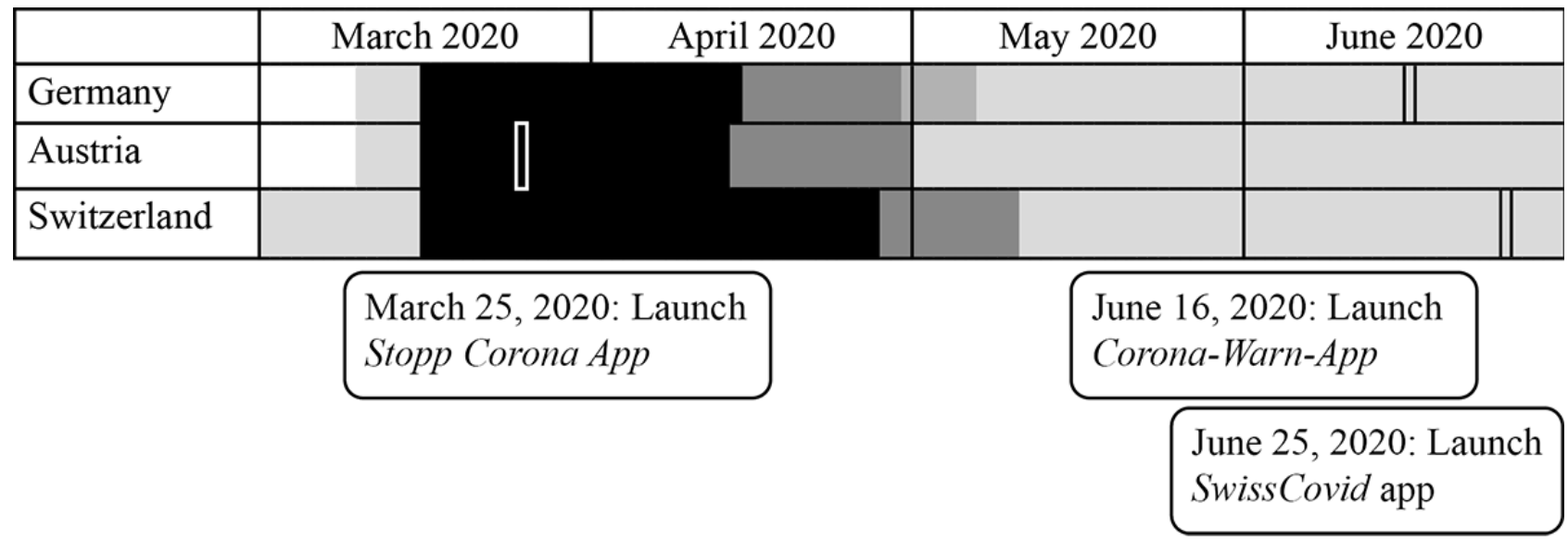

Although these apps have the same basic functions, there are some important differences among them. First, there are differences concerning the institution that launched the apps-the Swiss and German contact tracing apps were launched by the respective federal governments, whereas the Austrian app was launched by Red Cross Austria, a national nongovernmental organization. Second, the apps differ in the way in which users can report infection. For instance, German app users need to call a hotline after having received a positive COVID-19 test result [1]. Swiss app users receive a code from health authorities that needs to be entered into the app [2]. Austrian app users can alert their contacts directly without contacting any authority, but they need to register their phone numbers to avoid misuse [3]. The Austrian app also includes a symptom checker that allows for a direct alert if symptoms indicative of COVID-19 are entered [3]. Third, there are differences concerning the warning levels: the Swiss and Austrian apps have 2 warning levels ("no warnings" or "potential infection"), whereas the German app has an additional option called "unknown risk," which is useful in cases wherein the app was not activated long enough to make an assessment. Finally, there are also differences in the management systems used by these apps. In Europe, key management systems for such contact tracing apps include Pan-European Privacy-Preserving Proximity Tracing (PEPP-PT) [4] and Decentralized Privacy-Preserving Proximity Tracing (DP-3T) [5]. PEPP-PT aimed for a centralized data storage system, whereas DP-3T foresaw a decentralized data storage approach on individual phones, thereby aiming to increase data security and privacy [6,7]. The final versions of all 3 apps used the decentralized approach as promoted by DP-3T.
However, it appears that very few people have downloaded and are using these apps. Although surveys conducted in Spring 2020 reported acceptance rates of up to $70 \%$ for hypothetical contact tracing apps in Germany and Switzerland [8,9], only $25 \%$ and $31 \%$ of the total populations in Germany and Switzerland, respectively, had downloaded the app by October 30,2020 , with active user estimations ranging around $21 \%$ in both countries $[2,10]$. On the other hand, only $12 \%$ of the population in Austria had downloaded the Stopp Corona App by mid-April $2020[11,12]$, and download rates only increased marginally to $12.4 \%$ until October 2020 [13]. Modeling studies estimated that for contact tracing apps to be effective, the user rate needed to be at least $56 \%$ of the overall population [14] and that uptake rates need to be higher for decentralized data storage systems than for centralized ones [15]. Nevertheless, even lower user rates can have an impact on contact tracing and, consequently, on the ability of the system to control the spread of COVID-19 [16]. Contrary to those estimates, Maccari and Cagno [17] argued that Bluetooth-based, privacy-preserving contact tracing apps are of limited benefit due to potentially high false-positive rates and low sensitivity. Similarly, Rowe et al [18] contended that the French contact tracing app was implemented very quickly without taking into account the available evidence on viral spread. Overall, robust evidence on the actual effectiveness of contact tracing apps is lacking [19].

A large body of the existing literature has assessed users' perceptions, motivations, and barriers to using mobile health (mHealth) apps, particularly those related to chronic diseases and behavioral interventions [20-22]. Previous research on peoples' motivation to use mHealth apps suggests that user's perceived personal value is a crucial motivating factor [23-27], 
but other factors such as convenient use [26], high quality, trustworthy information provided through the apps [28], and previous experience and training with mobile technology particularly among older adults [27,29] are also mentioned. Stach et al [30] recently suggested a framework to evaluate mHealth apps, including user engagement, app functionality, aesthetics, information quality, therapeutic gain, users' subjective quality ratings, and perceived impact. Although research on mHealth apps generally focuses on individual usability, including the specific needs of patients with chronic conditions [22,31] or lifestyle support for a healthy diet or physical activity [32,33], contact tracing apps for pandemic control have an additional societal component. Accordingly, in the German context, Trang et al [34] found that appeals to the societal rather than personal benefit of contact tracing apps were most helpful to maximize uptake, particularly if the majority of the population was critical of the apps or undecided about using them. Other survey studies on the willingness to use contact tracing apps indicated that perceived benefit, expected performance, trust in government, and social influence were important motivating factors for using contact tracing apps, whereas privacy concerns were identified as the main hindering factor [8,35-40]. In line with these surveys, Keshet [41] identified a dichotomy in the comments related to Israeli news websites between supporters of contact tracing apps who see them as a protective measure for containment and opponents who see their civil rights violated. Despite issues pertaining to privacy and other civil rights being the most important concern against the use of contact tracing apps $[34,42,43]$, the privacy policies of these apps are not comprehensible by the average individual owing to their complexity [44]. Lack of privacy policies have also been identified for other mobile health apps [45], mHealth apps [46] and privacy concerns, including data safety and confidentiality, are known to negatively affect the uptake of mHealth apps in general [20,46-48].

How digital contact tracing apps are perceived will ultimately be a key factor in people's willingness to download and use them. Therefore, there is a need to better understand people's views on the use of digital technology to support COVID-19 contact tracing. The COVID-19 pandemic has been widely covered in the media, mirroring the immense public interest, with traditional mass media, including print and online news media, considered to be one of the preferred information sources $[49,50]$. The dynamic and uncertain situation at the beginning of the pandemic made people particularly reliant on such information sources. Previous studies have used media content analyses to assess public debates during the COVID-19 pandemic $[18,50]$, as well as other issues that affect population health $[51,52]$. Some other studies have combined media content analyses with surveys and interviews [53,54].

This study aimed to examine the early perceptions of people living in Germany, Austria, and German-speaking Switzerland toward digital contact tracing apps and compare them with frames as portrayed in the newspapers during the first wave of the COVID-19 pandemic. More specifically, the following research questions were addressed: (1) How did people living in Germany, Austria, and German-speaking Switzerland conceptualize and evaluate digital contact tracing apps during the COVID-19 lockdown in April 2020? (2) How were such apps portrayed in the newspapers, and were there any country-specific differences observed? (3) How did people's concepts and assessments intersect with the ongoing public debates and policies in April 2020? The countries investigated in this study are quite similar in terms of their culture (eg, language and a strong emphasis on privacy) and have democratic federalist political systems. By comparing data from similar countries, the observed differences can be interpreted in a more precise way [55]. In this context, one relevant difference is the circumstance that Austria had already launched a contact tracing app at the time of the interviews of this study, whereas Switzerland and Germany had not.

\section{Methods}

\section{Qualitative Interviews}

As part of the qualitative, longitudinal, and multinational SolPan (Solidarity in Times of a Pandemic) study [56], qualitative interviews were conducted with 159 individuals in Germany, Austria, and German-speaking Switzerland during the first COVID-19-related lockdown of April 2020. The SolPan Consortium includes 9 European countries (Austria, Belgium, Germany, France, Ireland, Italy, The Netherlands, German-speaking Switzerland, and the United Kingdom). It aims to explore peoples' experiences during the COVID-19 pandemic, particularly how people describe practices relating to solidarity. Interviews were conducted between April 6 and May 6, 2020, during which country-specific measures were in place to flatten the infection curve. This included various restrictions on movement and contact with other individuals, and the closure of schools, nonessential businesses, and public institutions.

Participants were recruited through online advertisement via university websites, social media networks, convenience sampling, and snowballing. To enable a variety of perspectives, participants were recruited with attention to a range of different demographics, including age, gender, income, household structure, geographic area, education, and employment. Participants received a study information leaflet prior to the interview, and verbal consent was obtained directly before the interview. A researcher-developed interview guide was used to guide the interview, which included a question regarding the use of mobile phones to assist in contact tracing (see Multimedia Appendix 1 for the interview guide). Interviews ranged from 25 minutes to 80 minutes in length; they were conducted online or by telephone and recorded on a digital recorder or using a video chat recorder compliant with the European General Data Protection Regulation. Only audio material was stored. The interviews were transcribed and subsequently pseudonymized. The study was approved by the ethics committees of the Technical University Munich (no. 208/20 S) and the University of Vienna (no. 00544). Interview transcripts were coded by all researchers by using an inductively generated coding scheme developed through the broader SolPan Consortium, using the ATLAS.ti 8.0 software (ATLAS.ti Scientific Software Development $\mathrm{GmbH}$ ). Coding was checked by a second researcher for consistency. Relevant text passages were extracted 
using the Atlas.ti query function, analyzed inductively, and summarized in a memo by the first author (BZ), thereby aiming to gain a higher level of abstraction by building concepts and categories. This analysis was performed separately for each country, and 2 authors (SM for Germany and Switzerland, and BP for Austria) double-checked and supplemented the analysis. Then, the concepts and categories were compared between the 3 countries and discussed among the researchers. Interviews were analyzed in German, but memos were written in English. Illustrative quotes were translated from German to English by a native German speaker (BZ) and double-checked by a native English speaker with good German skills (SM).

\section{Content Analysis of Newspaper Coverage}

In parallel to the interview analysis, a newspaper content analysis was conducted to assess what concepts, topics, and concerns were predominant at the time of the interviews across the countries. These insights were used to create a comparative framework analysis for country-specific interpretations and intercountry comparisons. The newspaper content analysis included articles published between March 15 and May 6, 2020, which includes the interview study period, and 3 weeks before the first interviews were conducted.

Three quality newspapers with a national readership and one tabloid from each country were included in the analyses. The selected newspapers are among those with the highest readership and were chosen based on equivalent functions in the respective national media systems [57], to allow for meaningful comparison. Newspapers were included to represent the mass media landscape of public debates for several reasons. First, even though newspapers lose readers to other channels, they still have considerable influence on coverage of other mass media, including social media for long-lasting issues [58]. Moreover, particularly large, high-quality newspapers are still considered a trustworthy source for reliable background information on health-related issues [25]. Finally, the publication format is reliably accessible. Accordingly, the Factiva database (Dow Jones Professional) [59] was used for a systematic search of articles that covered issues related to digital contact tracing. This database was selected because it covered the relevant newspapers, thus allowing for a unified search strategy, and was accessible to the research team. Relevant articles were retrieved with the following search algorithm using full-text search (in German): "(app OR technologie) AND (tracing OR tracking) AND (corona* OR covid-19).” Articles that reported on technology-based tracking or tracing in the context of COVID-19 were included in the study.

A codebook for the media content analysis was developed to collect the following variables: date of publication, medium, importance of topic (ie, contact tracing apps) in the article, country reference, article topics, app evaluation, and stakeholders cited (see Multimedia Appendix 2). The codebook was adapted from a previous study investigating newspaper coverage of medico-scientific issues [51]. Three coders collected these variables; they were trained in 2 online sessions wherein the codebook was discussed and tested in the team and refined upon discussion to make categories exclusive and intersubjectively understandable. For this aspect, 10 articles from each country were double-coded to identify the remaining ambiguities in the codebook. Since all instances of discordant coding could be easily resolved and were assignable to a source of uncertainty that was removed by clarifying the codebook, and because this analysis was used to supplement the qualitative analysis of the interviews, no formal reliability test was conducted. Descriptive statistics were calculated using Excel (Microsoft Corp). To identify key events, the distribution of articles over time as well as information from policy analyses were qualitatively linked to the collected variables. Key events were identified when several newspapers covered the same topic on the same day and/or when a topic was followed-up on several subsequent days.

\section{Results}

In German-speaking countries, both interview participants and newspaper coverage perceived and framed contact tracing apps predominantly as governmental surveillance tools. In the following sections, we first report the findings of the interviews, followed by results of the newspaper content analysis.

\section{Participants' Perceptions of Contact Tracing Apps}

In the 159 interviews conducted, more than two-thirds (110/159, $69.2 \%$ ) of the participants commented on contact tracing apps and were included in this analysis (Germany $n=29$, Austria $\mathrm{n}=56$, and Switzerland $\mathrm{n}=25$ ). Table 1 presents the demographics of the study participants. 
Table 1. Demographic distribution of study participants.

\begin{tabular}{|c|c|c|c|}
\hline \multirow[t]{2}{*}{ Characteristic } & \multicolumn{3}{|l|}{ Value, $\mathrm{n}(\%)$} \\
\hline & Germany $(n=29)$ & Austria $(\mathrm{n}=56)$ & Switzerland $(\mathrm{n}=25)$ \\
\hline \multicolumn{4}{|l|}{ Age (years) } \\
\hline $18-30$ & $4(14)$ & $11(20)$ & $7(28)$ \\
\hline $31-45$ & $14(56)$ & $11(24)$ & $3(17)$ \\
\hline $46-60$ & $4(36)$ & $20(59)$ & $6(40)$ \\
\hline $61-70$ & $6(29)$ & $12(25)$ & $4(17)$ \\
\hline$>70$ & $1(3)$ & $2(3)$ & $5(17)$ \\
\hline \multicolumn{4}{|l|}{$\operatorname{Sex}^{\mathrm{a}}$} \\
\hline Female & $14(48)$ & $34(61)$ & $14(56)$ \\
\hline Male & $15(52)$ & $22(39)$ & $11(44)$ \\
\hline \multicolumn{4}{|l|}{ Household } \\
\hline Single & $7(24)$ & $15(27)$ & $7(28)$ \\
\hline Couple & $10(34)$ & $20(36)$ & $8(32)$ \\
\hline Living with child or children under 12 years & $8(28)$ & $7(13)$ & $1(4)$ \\
\hline Living with child or children above 12 years & $2(7)$ & $8(14)$ & $4(16)$ \\
\hline Other & $2(7)$ & $6(11)$ & $5(20)$ \\
\hline \multicolumn{4}{|l|}{ Rural/urban } \\
\hline Big town (eg, capital, $>500,000$ population) & $12(41)$ & $30(54)$ & $8(32)$ \\
\hline Mid-sized or small town & $9(31)$ & $15(27)$ & $5(20)$ \\
\hline Rural (eg, village) & $8(28)$ & $11(20)$ & $12(48)$ \\
\hline \multicolumn{4}{|l|}{ Employment status } \\
\hline Employed (long-term contract) & $17(59)$ & $21(38)$ & $9(36)$ \\
\hline Self-employed & $2(7)$ & $9(16)$ & $3(12)$ \\
\hline Employed (short-term or precarious contract) & $1(3)$ & $4(7)$ & $5(20)$ \\
\hline Unemployed & $4(14)$ & $4(7)$ & $1(4)$ \\
\hline Retired & $4(14)$ & $14(25)$ & $6(24)$ \\
\hline Other & $1(3)$ & $4(7)$ & $1(4)$ \\
\hline \multicolumn{4}{|l|}{ Education level } \\
\hline$<10$ years & $0(0)$ & $5(9)$ & $8(32)$ \\
\hline 10-14 years (eg, high-school diploma) & $9(31)$ & $18(32)$ & $3(12)$ \\
\hline Higher education & $20(69)$ & $33(59)$ & $14(56)$ \\
\hline \multicolumn{4}{|l|}{ Household net income per month ${ }^{b}$ (before the COVID-19 pandemic) } \\
\hline$\leq € 1400$ (US $\$ 1693$ ) or $\leq \mathrm{CHF} 4000$ (US $\$ 4472)$ & $3(10)$ & $7(13)$ & $3(12)$ \\
\hline$€ 1401-3000$ (US \$1694-3628) or CHF 4001-7000 (US \$4473-7826) & $7(24)$ & $23(41)$ & $8(32)$ \\
\hline$>€ 3000$ (US \$3628) or >CHF 7000 (US \$7826) & $19(66)$ & $26(46)$ & $14(56)$ \\
\hline Total interviews $(\mathrm{N}=110)$ & $29(26.3)$ & $56(50.9)$ & $25(22.7)$ \\
\hline
\end{tabular}

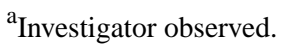

${ }^{\mathrm{b}}$ Self reported; categories were adjusted based on country-specific income levels.

Most participants stated that they had heard about the option of mobile phone-based contact tracing, but several participants seemed to be uncertain about the function and scope of contact tracing apps or lumped together different technologies. For instance, the concept of individual contact tracing was sometimes confused with population surveillance measures, such as anonymous mobile phone tracking to analyze population behavior during restrictions. These different conceptions of how 
contact tracing could be employed were also a source of confusion and uncertainty about what mobile phone-based tracing would actually entail.

\begin{abstract}
What I don't quite understand here is whether it's about who is positive or simply controlling masses of people, such as [navigation systems] in traffic. That uses data to control traffic volume. I don't know exactly how it is supposed to work, that the people who are positive sign up themselves, so to say, or whether the database is maintained and you don't even know whether you are in it or not. [Swiss participant 15]
\end{abstract}

A few participants also stated that they were not well informed about the topic at the time of the interview, indicating that they were not sure whether they could endorse the use of digital tracking tools due to their limited understanding or stating that they were aware of the tools but had not yet formed an opinion on their use.

\section{Perceiving Contact Tracing Apps as Governmental Surveillance Tools}

Participants perceived contact tracing apps as governmental surveillance tools and embedded them in a broader societal context (Figure 2). However, "surveillance" was framed by participants in different ways. Some participants viewed such surveillance as a mechanism that empowers the authorities to control individual compliance with measures, which provoked negative sentiments. By contrast, other participants justified such contact tracing apps as surveillance tools for authorities that helped contain the pandemic without too many further restrictions. Yet other participants balanced the perils of surveillance against the specific needs to contain the pandemic:

\section{Controlling is not necessarily a threat. [German participant 7]}

Although German and Swiss participants generally spoke about contract tracing apps only when asked about them specifically, approximately $20 \%$ of Austrian participants brought up the topic spontaneously, and their responses were also often more elaborate in length than the responses from Swiss and German participants.

Figure 2. Illustration of interview participants' perceptions of digital contact tracing apps during the first wave of the COVID-19 pandemic (data collected in April and early May 2020).

Embedded in a broader societal context:

- Political dimension: compatibility with democracy

- Technological dimension: generalization

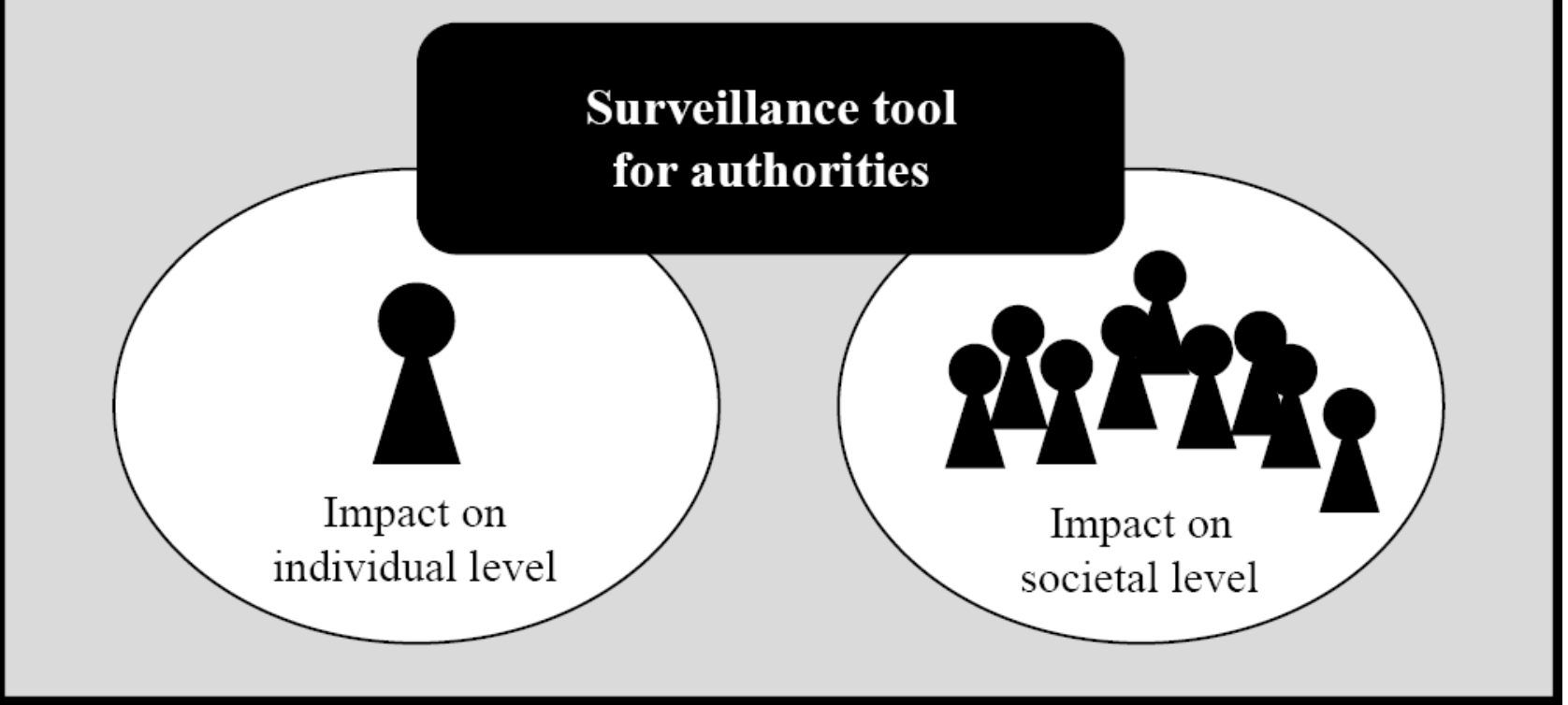

\section{Compatibility With Democracy}

In all three countries, participants related contact tracing apps to Asian countries, such as China, which had already been using digital contact tracing technology for viral containment when the interviews were conducted. Although a few participants referred to the success of Asian countries in virus suppression as proof of the usefulness of these applications, most others used a comparison with "totalitarian states" as an argument against contact tracing apps, stating that the tools were incompatible with democratic values and rights.

Yes, I've heard about [the idea of contact tracing apps] and I completely reject it, I must say because my own data is simply too insecure, not protected and I don't want the state or whoever evaluates this data to know exactly where I was, what I did. And it also has a touch of the Chinese state or something [sic]. 
In Asia, it is already being practiced without people critically questioning it. But I am absolutely against it. [German participant 41]

By contrast, some participants framed contact tracing apps as tools that support authorities to control the viral spread:

I really believe in these apps because I think that if they are handled consistently, they can really reveal a lot of information to the authorities to develop certain measures or to react to the course of the disease [sic]. [German participant 3]

Participants also indicated a list of prerequisites that they considered crucial for a contact tracing app to be compatible with democracy: trust, privacy, voluntariness, and a time limit on data retention and use. The first prerequisite concerned the level of trust in national and local authorities. Since contact tracing apps were perceived as a surveillance measure of authorities, the level of trust towards these authorities was an important factor for people's willingness to participate. Participants in all three countries expressed the fear that the pandemic could be exploited by governments to install long-term surveillance systems, weighing the possible benefits of virus containment against the erosion of human rights:

I understand, of course, that this can be used to do contact tracing and potentially contain virus spread and I can see its usefulness. It's just, I'm struggling with the question of how much a crisis justifies intervening in basic human rights? And I think the problem is, if there is no pushback, then you might end up in a situation. I mean, I think that is what happened after the terrorist attacks in London and the US, that suddenly the NSAs of the world are created. And then nobody really knows what kind of information they actually have. And that shouldn't be the case in a democracy. So I think that citizens should be aware that some things are very difficult to undo later on. [German participant 42]

The distrust of authorities was expressed most prominently by Austrian participants, who repeatedly called for more transparent communication about the app. They criticized a lack of clarity in communication surrounding how location and movement data were analyzed, possible extensions regarding the functionality of the app, or the role of the Austrian government in an app that was originally launched by Red Cross Austria, a nongovernmental organization. Austrian participants also seemed to be uncertain whether the app could be used for personalized tracking later on. They feared penalties for noncompliance or expressed concerns about a creeping loss of privacy. Others indicated skepticism surrounding a lack of clarity of how data would be used from the app.

So on the one hand the minister says: "Watch out because of this data on Facebook or whatever, or with people that want to call you or steal your login." On the other hand, he says we should use the Red Cross app. But they don't say what happens to the app or your data in the background [i.e. for other than contract tracing purposes], do they? I don't quite believe them, unfortunately. That's the only thing I don't really believe, to be honest. [Austrian participant 46]

In the second prerequisite, many participants stressed the need to develop contact tracing apps that were compatible with existing privacy and data protection regulations:

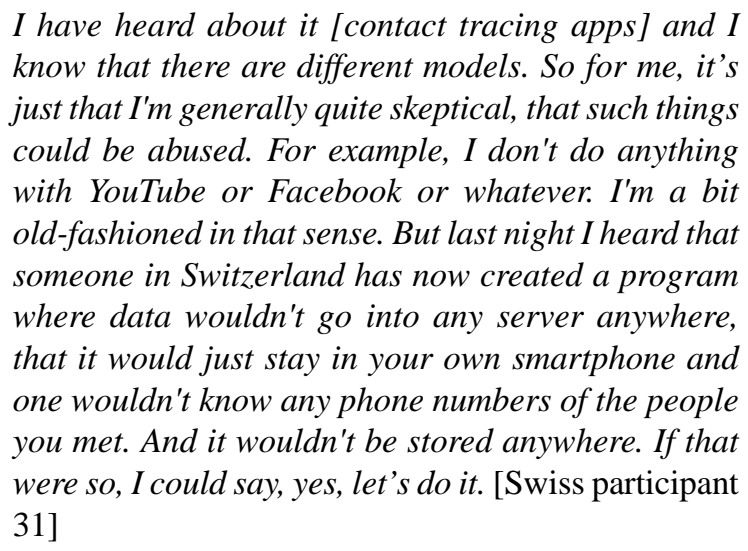

Third, many participants believed that voluntariness was a key prerequisite for contact tracing apps to be compatible with democratic values and human rights. Although participants in all three countries mentioned this topic, we found it most predominantly mentioned in the Austrian data. Some Austrian participants even envisaged the possibility of "class action lawsuits" [Austrian participant 25] against the government and considered "strategies how to defend" themselves [Austrian participant 27] in case of the possibility of compulsory app use. Two Austrian participants even stated that they would rather die than be monitored by the government.

Finally, participants also thought that these tracing apps should be used temporary and only in the context of special circumstances such as the COVID-19 pandemic. Some participants suggested that the data should be erased when it was no longer needed, whereas others reiterated their concern that the data should only be used for the purposes indicated and not to build a surveillance state. One participant noted that although it made sense to use the app now, they intended to uninstall it by the end of the year, whereas another participant noted that these apps would no longer be justified when vaccines or other treatments are available.

\section{Embedding Contact Tracing Apps in a General Technological Context}

Participants from all countries linked tracing apps to other applications that collect data, such as social media, credit cards, or shopping cards, with the underlying concern that their data might be misused. The idea that others might be able to watch over one's actions and whereabouts was unnerving for some participants, particularly concerning uncertainty to where the data would be stored, who would have access to data for how long, and whether the crisis would erode privacy principles that would later be hard to re-establish:

I don't know, with technology, I always get the impression that these things creep in like crazy. Like we accept everything with every normal app because we only have the [binary] option not to use it or to accept the terms of use. [Austrian participant 45] 
Others were specifically concerned about the way the government or other powerful actors might use the information in the future:

\begin{abstract}
We reveal so many things but we don't know yet how this could be used against us in the future [...] So people should be careful and I believe that the state has far too much power over us in that context. [Austrian participant 5]
\end{abstract}

Some participants seemed generally suspicious of surveillance technologies because of their potential for abuse, extending their suspicion of platforms such as YouTube or Facebook to digital tracking tools. Others said that their smartphones were already tools for individual surveillance. They suggested leaving smartphones at home to avoid being traced, or jokingly noted that they speak in dialect so that those "listening" will not understand:

\section{I have a Huawei phone and I believe that the data will be delivered to China. That is why I always speak dialect because then the Chinese cannot understand me [laughing] [sic]. [Austrian participant 6]}

Moreover, some participants worried that this technology could negatively affect not only their own lives but also how people relate to each other:

For me, it is not an option for everybody to be so high-tech. That's what it's all about. That you can see where somebody is. Who has been with whom in some way and so on. I find that threatening. I find that threatening. And I don't really want that. [Swiss participant 22]

Embedding contact tracing apps in their general attitude towards technology led some to generally reject contact tracing apps. For others, by contrast, such consideration relativized their privacy concerns. For instance, one participant noted that they had already been recorded a hundred times on camera when driving into the city. Other participants suggested and expressed acceptance that people had long lost control over their data and their lives.

\section{Impact on the Societal Level}

Some participants framed contact tracing apps as a resource for the common good, stressing their function to help contain the viral spread and protect at-risk individuals. This was particularly pronounced in Germany and Switzerland, whereas only very few Austrian participants articulated this stance. One participant even felt that it was a duty to use the available technology to fight the risk of infection:

\section{But I think that's good, I'm not concerned that [contact tracing apps restrict] freedom and privacy issues, instead I see the benefits. And in South Korea, [digital contact tracing] has really helped to reduce the number of infected people. And I believe that there is a duty to support this. [German participant 35]}

Others perceived tracing apps as a fast-track back to normality, increasing people's "freedom to move around" [German participant 26] and as a tool that "makes us all, as a society, more flexible" [Swiss participant 17]. By contrast, a few participants (particularly those in Austria) expressed fears of social pressure, stigma, and panic. One Austrian participant compared the app to the Star of David during the National Socialist Regime that singled out Jewish people. In a similar manner, this participant argued, the app stigmatizes infected people and makes them visible to everyone. It should be noted here that neither of the apps we report on here actually includes the function of making infected individuals visible to others.

\section{Impact on the Individual Level}

Some participants also focused on the impact the app might have on the individual level. Some of them focused on the potential personal benefit when using the app by framing contact tracing apps as a useful individual warning and information tools to proactively avoid COVID-19 infection. They hoped to get warnings to avoid risky situations, thereby decreasing personal uncertainty and providing orientation: "My wife and I, we would download and use it [contact tracing app] immediately and hope to be warned if someone comes too close. Or has come too close" [German participant 12]. This view was mainly taken by participants without practical experience with these apps, as none of the apps include such an immediate warning function. Moreover, contact tracing apps were framed as tools that affect individual responsibility. A few individuals perceived them as a tool that enables them to take individual responsibility: "I would probably also install the app on my cell phone, just because I find it helpful for me to know that if I picked up the virus somewhere, I could inform people, hey, watch out and stuff." [Austrian participant 15]. One participant said that they wished people would behave more responsibly, indicating that they felt contact tracing apps were only necessary because people were not acting responsibly enough.

Many of those participants who were skeptical of tracing apps were concerned about their privacy, expressing uneasiness about such tools "lying on the bedside table" [German participant 4] and comparing mobile phones to "personal diaries" [German participant 22] that they considered very private. Participants also expressed concerns about data protection in connection with contact tracing apps. To protect their data safely, some advocated for local data storage and against data silos.

\section{Comparative Content Analysis of Newspaper Coverage}

To further contextualize our participants' perceptions of contact tracing apps, we also performed a content analysis of newspaper coverage on contact tracing apps during the interview period (April 6 to May 6, 2020). By quantitatively and qualitatively comparing coverage from the four most-read newspapers of each country, we identified country-specific differences that laid out the basis for comparative interpretation as presented later in the discussion.

A total of 194 newspaper articles from 12 newspapers of the three German-speaking countries were included in the media content analysis (see Table 2). The nature of newspaper coverage regarding tracing apps was similar in the three countries studied, but Germany tended to have longer articles than the other two countries (see Multimedia Appendix 3). 
Table 2. Sampling of newspapers and articles.

\begin{tabular}{llll}
\hline Country and newspaper & Genre & Publisher & Number of included articles \\
\hline Switzerland & & & 31 \\
Neue Zürcher Zeitung & International quality newspaper & NZZ Mediengruppe & 19 \\
Tages Anzeiger & National quality newspaper & Tamedia & 10 \\
Neue Luzerner Zeitung & Regional newspaper & CH Media & 5 \\
Blick & National tabloid & Ringier & 27 \\
Germany & & & 23 \\
Süddeutsche Zeitung & International quality newspaper & Süddeutsche Zeitung GmbH & 16 \\
Die Welt & International quality newspaper & Axel Springer Verlag & 1 \\
taz, die tageszeitung & National quality newspaper & Taz Verlags-genossenschaft & 23 \\
BILD & National tabloid & Axel Springer Verlag & 16 \\
Austria & & & 23 \\
Kurier & National quality newspaper & Kurier Zeitungsverlag und Druckerei GmbH \\
Der Standard & National quality newspaper & Standard Verlagsgesellschaft m. b. H. & 23 \\
Die Presse & National quality newspaper & Die Presse Verlags-Gesellschaft m.b.H. \& Co KG \\
Krone.at & National tabloid & Mediaprint & 0 \\
\hline
\end{tabular}

\section{Frames and Country-Specific Key Events}

From the end of March to the beginning of April, German-language newspapers in all three countries reported geolocation or Wi-Fi-based tracking apps used for the anonymous analysis of population mobility or individual surveillance. Articles reported anonymous mobile phone data analysis to assess population mobility during the lockdown in all three countries. German and Austrian newspapers critically reported political discussions to use nonanonymous data for individual surveillance and raised fundamental concerns regarding basic human rights and democratic legitimacy. Swiss newspapers reported predominantly positive aspects and did not raise such concerns. In Austria, newspapers focused those concerns directly on the Austrian app, which was launched in March. In this context, the president of the first chamber of the Austrian Parliament, Wolfgang Sobotka, speculated publicly about making the Austrian app mandatory in an interview with the Austrian news magazine profil. This fueled already-existing concerns about civil rights and privacy violations in that context.

Similarly, the German health minister Jens Spahn attracted much critical coverage when, on March 25, 2020, he publicly considered including new options for tracking and surveillance in the updated German Epidemic Law. Even though newspapers in Germany reacted with similar concerns as those in Austria, the topic did not stay in the news as long as in Austria. Nevertheless, the launch of Robert Koch-Institut's "data donation app" on April 9, 2020, was accompanied by predominantly critical coverage about lack of transparency and insufficient data protection.

Starting at the end of March, the Swiss and German newspaper coverage discussed proximity tracing (meaning registering close contacts rather than using location data) as a possible assistance tool for contact tracing after the so-called lockdown period. Even though data protection and privacy issues were discussed, proximity tracing was introduced to potentially overcome these issues. To that end, the German and Swiss newspapers evaluated such applications more positively than Austrian newspapers, which were predominantly critical towards the potential privacy implications of the Austrian app. In mid-April, German and Swiss media picked up disagreements on data storage mechanisms within the PEPP-PT research consortium. Swiss coverage focused on the Swiss epidemiologist Marcel Salathé who argued for a decentralized data storage system. In that context, Swiss newspapers reported supportively about the Swiss contact tracing app in development. In Germany, where researchers had initially favored a centralized data storage system, the same éclat caused discussions about data protection requirements. On April 27, 2020, the German government announced that they had decided on a decentralized data storage system. This was evaluated positively in the newspapers. All three countries also compared nationally discussed solutions of contact tracing apps with international applications, especially those in active use in Israel, China, and South Korea, and criticized those as being largely inconceivable in Western European democracies. Country-specific framings and key events are presented in detail in Multimedia Appendix 4.

\section{National and International Views on Coverage}

In Swiss and German coverage, the international collaboration of researchers involved in research needed for the development of such an app was mentioned more often than in Austria (see Table 3). 
Table 3. Stakeholders cited in newspaper articles.

\begin{tabular}{|c|c|c|c|}
\hline \multirow[t]{2}{*}{ Stakeholders cited } & \multicolumn{3}{|l|}{ Mentions, n (\%) } \\
\hline & Germany $(n=67)$ & Austria $(\mathrm{n}=62)$ & Switzerland $(\mathrm{n}=65)$ \\
\hline Governmental actors or politicians & $28(42)$ & $30(48)$ & $36(55)$ \\
\hline Nongovernmental actors & $9(13)$ & $11(18)$ & $1(2)$ \\
\hline Scientific and medical experts & $22(33)$ & $5(8)$ & $32(49)$ \\
\hline Legal experts & $4(6)$ & $18(29)$ & $9(14)$ \\
\hline Experts from humanities or social sciences & $9(13)$ & $1(2)$ & $2(3)$ \\
\hline Celebrities or VIPs & $1(1)$ & $1(2)$ & $0(0)$ \\
\hline Civil society & $2(3)$ & $0(0)$ & $2(3)$ \\
\hline Private companies & $4(6)$ & $3(5)$ & $4(6)$ \\
\hline Other & $0(0)$ & $1(2)$ & $0(0)$ \\
\hline
\end{tabular}

In general, Austrian coverage tended to focus more on a national perspective than Swiss and German coverage, where newspapers repeatedly referred to the international PEPP-PT research initiative. This, in turn, led to coverage on the topic of centralized versus decentralized data storage in these two countries, which did not come up as frequently in Austrian newspaper coverage (see Table 4). In all three countries, tracing and tracking applications were repeatedly connected to totalitarian surveillance states, such as China, or even Asian democracies such as South Korea, where surveillance apps were used as containment strategies.

Table 4. Topics mentioned in newspaper articles.

\begin{tabular}{|c|c|c|c|c|c|c|}
\hline \multirow[t]{2}{*}{ Topic } & \multicolumn{2}{|c|}{ Germany $(\mathrm{n}=67)$} & \multicolumn{2}{|l|}{ Austria $(\mathrm{n}=62)$} & \multicolumn{2}{|c|}{ Switzerland $(\mathrm{n}=65)$} \\
\hline & $\begin{array}{l}\text { Topic total, n } \\
(\%)\end{array}$ & $\begin{array}{l}\text { Main topic }{ }^{\mathrm{a}}, \mathrm{n} \\
(\%)\end{array}$ & $\begin{array}{l}\text { Topic total, } \mathrm{n} \\
(\%)\end{array}$ & $\begin{array}{l}\text { Main topic, } \mathrm{n} \\
(\%)\end{array}$ & $\begin{array}{l}\text { Topic total, } \mathrm{n} \\
(\%)\end{array}$ & $\begin{array}{l}\text { Main topic, } \mathrm{n} \\
(\%)\end{array}$ \\
\hline $\begin{array}{l}\text { GPS motion tracking at population level } \\
\text { (anonymized) }\end{array}$ & $3(4)$ & $2(3)$ & $4(6)$ & $0(0)$ & $16(25)$ & $6(9)$ \\
\hline GPS motion tracking on an individual level & $12(18)$ & $4(6)$ & $13(21)$ & $6(10)$ & $4(6)$ & $1(2)$ \\
\hline "Datenspende" app (Robert Koch-Institut) & $8(12)$ & $5(7)$ & $0(0)$ & $0(0)$ & $0(0)$ & $0(0)$ \\
\hline Development of contact tracing apps & $14(21)$ & $10(15)$ & $20(32)$ & $11(18)$ & $26(40)$ & $9(14)$ \\
\hline Functioning of contact tracing apps & $19(28)$ & $9(13)$ & $18(29)$ & $6(10)$ & $24(37)$ & $4(6)$ \\
\hline Centralized vs decentralized data storage & $12(18)$ & $4(6)$ & $1(2)$ & $1(2)$ & $7(11)$ & $0(0)$ \\
\hline Legal or ethical issues regarding tracing apps & $5(7)$ & $3(4)$ & $38(61)$ & $19(31)$ & $33(51)$ & $15(23)$ \\
\hline Other relevant topics & $4(6)$ & $4(6)$ & $0(0)$ & $0(0)$ & $0(0)$ & $0(0)$ \\
\hline $\begin{array}{l}\text { Tracking/tracing technology that not the main } \\
\text { topic }\end{array}$ & $25(37)$ & $\mathrm{N} / \mathrm{A}^{\mathrm{b}}$ & $17(27)$ & N/A & $29(45)$ & N/A \\
\hline
\end{tabular}

aA topic was defined as the "main topic" if it was mentioned in the title or the first paragraph of the article. There was only one main topic per article but otherwise an indefinite number of topics could be coded if necessary.

${ }^{\mathrm{b}}$ Not applicable.

\section{Discussion}

Even though policymakers in Germany, Austria, and Switzerland framed contact tracing apps as safe and helpful tools to contain the viral spread, most participants perceived contact tracing apps as governmental surveillance tools. This perception was represented in all interviews and across all three countries. What varied, however, was how people framed and assessed this form of governmental surveillance. Many participants reflected on the compatibility of contact tracing apps with Western democracies. Newspaper coverage periodically framed these apps in a similar fashion by using three frames that were predominantly covered in April 2020: (1) critical examination of the impact of contact tracing apps on individual privacy and the compatibility with existing data protection regulations; (2) simultaneous framing and comparison with digital surveillance tools used in Asian countries, especially China, provoking a contrasting view to Western democracies; and (3) periodical focus on country-specific political and scientific stakeholders.

Privacy issues were a predominant concern expressed by participants and in newspaper coverage; these issues also mirror the early concerns expressed in the literature $[43,60]$. People were concerned about the impact of contact tracing apps on individual freedom and privacy, in line with concerns commonly 
expressed in the newspaper articles reviewed in this study. Participants emphasized that it was a matter of principle for them: The use of a digital tool that was perceived to be so intrusive in people's privacy should never be made mandatory. Indeed, the voluntariness of contact tracing apps is also debated and emphasized by experts, including what voluntariness means in this context [61-63]. Nevertheless, ethicists have more recently criticized this emphasis on privacy and pointed to other ethical issues that were left aside in app development, such as safety and effectiveness [60,64], social justice issues [65,66], or the potentially problematic policy influence of Apple and Google in that context $[18,67]$.

\section{Possible Explanations for Low Uptake Rates}

At the time of writing this manuscript, over half a year after the launch of the respective contact tracing apps, app developers and authorities were facing lower user rates than initially expected [8,9]. This constitutes some tension with other government measures that also limited people's freedom but were readily accepted; for example, the majority of people in Germany and Austria supported compulsory face mask use a few months later $[12,68,69]$.

One reason for this might be that the early perception as a surveillance tool for authorities left many people reluctant to use contact tracing apps. The observed tendency to put these contact tracing apps into a broader context of technological surveillance tools and privacy concerns might have triggered general concerns of privacy that are known to be particularly important in the German-speaking areas [70], and the same has been reported in the French context [18]. Newspapers reporting the use of contact tracing and tracking apps in Asian countries might have further deepened the impression that these applications are not aligned with democratic principles of individual privacy and freedom since these applications were considered by interview participants and newspapers alike to be not compatible with privacy regulations and democratic principles as understood in the European context.

The broad contextualization of contact tracing apps makes factual information about the app itself (such as it contributes to controlling the pandemic, data is anonymized, and location tracking impossible) less effective, as people tend to use pre-existing concepts from other technologies to avoid cognitive dissonance, which occurs when expectations and performance contradict each other [71]. Thus, even though the performances of the apps are privacy-friendly, those who are generally skeptical towards digital tools and surveillance still expect them to be dangerous, despite the crucial efforts of app developers and policymakers. This points to the underlying and unsolved issues of regulating digital tools, data ownership, and nontransparent use and economization of data [67].

Likewise, Barth and Jong [72] suggested that the privacy paradox, in which people share some information willingly but are reluctant to share information with others, was relying on risk-benefit assessment (see also [60]). It is plausible that a subset of people considers contact tracing apps to have more privacy-related risks than benefits. Indeed, the currently available contact tracing apps have little personal benefit but promise to serve the common good by contributing to pandemic containment. Proof of effectiveness has been difficult to demonstrate thus far because user rates have been lower than originally suggested [14], so potential benefits could not unfold, and it is challenging to collect relevant data for quality control due to privacy constraints. Showing the benefits of contact tracing apps on an individual and a societal level might increase the uptake, but would need to be reliable, ideally through direct empirical evidence of effectiveness.

\section{Public Trust and Transparent Communication}

Particularly in Austrian interviews, people criticized what they perceived to be the absence of transparent political communication. For example, the public speculation of the president of the first chamber of the Austrian parliament, Wolfgang Sobotka, that the use of the Austrian app may become mandatory seemed to undermine people's trust. It also influenced participants' responses in the days following this particular event. Although most Austrian participants trusted the Red Cross, the fact that Red Cross launched the app was often considered less relevant than the function of the app as a surveillance tool for authorities. Trustworthiness was generally a less dominant topic in Swiss and German interviews. In both countries, epidemiologists and app developers were frequently given a voice in newspapers. For instance, newspaper coverage followed discussions of app developers about centralized or decentralized data storage, or it critically reflected on political considerations connected to voluntariness and whether to introduce a legal basis for surveillance measures. These issues were publicly discussed and addressed prior to the release of contact tracing apps in June, and upon their launch, it was already legally binding that apps could not become compulsory and needed to employ decentralized storage systems. This is in sharp contrast with other examples, such as in France, where a centralized storage system was implemented despite privacy concerns [18]. Such discussions prior to launch might have promoted public trust in authorities and could be a possible reason for the higher relative uptake numbers in Germany and Switzerland as compared with those in Austria. This is further supported by our finding that German and Swiss newspapers framed the discussion, particularly the scientific discussion behind app development, from a more international perspective, whereas Austrian newspapers focused on the national issues of the already-released app. In line with our findings, recent ethical inquiries have also identified public trust as the most critical element for the uptake of contact tracing apps [18,40,73-75].

\section{Conflation of Different Mobile Phone-Based Tracing and Tracking Apps}

Newspapers and interview participants alike often conflated different tracking applications (anonymous geolocation or Wi-Fi data population analysis vs. real-time personal GPS tracking versus Bluetooth-based proximity tracing). This seems to have confused people and may have solidified concerns surrounding the possibility of ubiquitous surveillance because instances where de-identified information was collected were interpreted as personalized tracking. These uncertainties and misconceptions seemed to be associated with uneasiness and general skepticism. These findings highlight the difficult task for governments to communicate about the apps they plan to introduce transparently, 
clearly, and simply, while including sufficient information to allow people to distinguish between different applications [76,77].

\section{Limitations}

This study did not assess the exact prevalence of specific views on, or experiences with, contact tracing apps in the general population in the three countries or regions examined. Instead, we sought to explore how people describe their practices regarding contract tracing apps where they have had personal experience, and their normative, factual, and emotional reference points when discussing the design, utility, and effect of digital contact tracing. To contextualize the data obtained from the large-scale interview study, we also carried out an analysis of mainstream news media in the three countries or regions that was limited by the fact that newspapers were the only format examined and other mass media (such as television, radio, and social media) were excluded. No reliability testing was conducted because we interpreted the data relationally and qualitatively, looking for relationships rather than statistical significance. As such, this article provides context-specific insights into digital tracking tools during a specific period in the COVID-19 pandemic. Even though we sought a balanced demographic distribution, the final sample of interview participants is slightly skewed towards people with higher educational levels (more than 10 years), those who are under 70 years of age, and those in the Austrian sample living in urban areas. However, because this is a qualitative analysis not aiming for statistical representativeness, every view was considered independent of how many participants had stated this view. Given that several interviewees supported every view we report and that we were able to draw what in the grounded theory approach is called a "middle-range theory," we conclude that we have reached satisfying theoretical saturation [78]. Although we did report when issues were mentioned particularly frequently or particularly rarely, any quantification in terms of how many citizens support these views is subject to further quantitative inquiries, such as follow-up surveys, which go beyond the scope of this paper. In the Swiss context, only the German-speaking part is covered both in terms of newspaper coverage and interview participants. Since there are considerable cultural differences between Swiss language regions [79], our findings are limited to the German-speaking part of Switzerland.

\section{Conclusions}

Newspapers from and people living in German-speaking countries perceived digital contact tracing apps as surveillance tools popularized by authorities during the first wave of the COVID-19 pandemic in April 2020, attributing a broad range of interpretations, evaluations, and impact to this perception. Even though privacy was a common concern among participants, many also framed surveillance in a positive way and saw contact tracing apps as tools that could benefit society in containing the viral spread. Others saw the potential for personal and societal benefit, affording users better control over their exposure risk. Voluntariness and trustworthiness were most frequently discussed by Austrian participants, in line with Austrian newspaper coverage and political discussions at that time. The early launch of the Austrian Stopp Corona app has, on the one hand, made the topic more immediately relevant for both study participants and mass media. On the other hand, ongoing debates about the voluntariness and the use of apps for checking individual compliance through the authorities might have caused more severe and lasting rejections in Austria than in Germany or Switzerland, where the relative uptake of the apps was slightly higher.

Although communication from authorities and app developers shapes peoples' early perceptions of contact tracing apps, their previous experiences and expectations with authorities and digital tools also play an important role. Thus, when authorities plan to implement new digital tools and practices in the future, they should be very clear in communicating the objectives, the contribution of this technology, and how it differs from other, possibly similar, tools that may be problematic or may have been previously used in a problematic way. Similarly, even in cases where there is a pressing need for the use of new tools, it is important to address publicly and solve ethical, legal, and social issues related to such technologies prior to their launch-existing concerns related to new technologies need to be addressed proactively. Finally, to overcome the privacy paradox, the effectiveness of contact tracing apps needs to be evaluated and communicated.

\section{Acknowledgments}

The interview study was conducted as part of the SolPan consortium, and we acknowledge all consortium members for their valuable discussions and contributions concerning study design and strategy. We particularly thank Dr. Katharina Kieslich for her insights into Austrian contact tracing app policies and student assistants Magnus Tibbe and Justus Bredthauer for extracting data from Austrian and Swiss newspaper articles. This work was supported by the German Federal Ministry for Education and Research (Bundesministerium für Bildung und Forschung; Grant number 01K120510), which had no role in the project design; in the collection, analysis, or interpretation of data; in the writing of the article; or in the decision to submit the manuscript for publication.

\section{Conflicts of Interest}

None declared.

\section{Multimedia Appendix 1}

Qualitative interview guide (SolPan; translated German version, April 2020). 


\section{Multimedia Appendix 2}

Codebook used for newspaper content analysis.

[DOCX File, 29 KB-Multimedia Appendix 2]

\section{Multimedia Appendix 3}

Supplementary tables of newspaper content analysis.

[DOCX File, 13 KB-Multimedia Appendix 3]

\section{Multimedia Appendix 4}

Country-specific analysis of frames portrayed in newspaper coverage over time.

[DOCX File, 24 KB-Multimedia Appendix 4]

\section{References}

1. Die Corona-Warn-App: Unterstützt uns im Kampf gegen Corona. German Federal Government. 2021. URL: https://www. bundesregierung.de/breg-de/themen/corona-warn-app [accessed 2021-01-11]

2. SwissCovid App. Swiss Federal Office of Public Health. 2021. URL: https://bag-coronavirus.ch/swisscovid-app/ [accessed 2021-01-11]

3. Questions and answers about the Stop Corona app. Stop Corona App (Austrian Red Cross). 2021. URL: https://www. stopp-corona.at/faq stopp corona app/ [accessed 2021-01-11]

4. PEPP-PT Documentation. PEPP-PT Consortium. URL: https://github.com/pepp-pt/pepp-pt-documentation [accessed 2021-01-11]

5. DP-3T Documents. DP-3T Consortium. URL: https://github.com/DP-3T/documents [accessed 2021-01-11]

6. Grube T, Heinrich A, Stroscher J, Schomberg S. Data security of Corona apps according to the GDPR (Article in German). Data Protection Data Security 2020 Jul 27;44(8):501-505. [doi: 10.1007/s11623-020-1314-0]

7. Ahmed N, Michelin RA, Xue W, Ruj S, Malaney R, Kanhere SS, et al. A Survey of COVID-19 contact tracing apps. IEEE Access 2020;8:134577-134601. [doi: 10.1109/access.2020.3010226]

8. Altmann S, Milsom L, Zillessen H, Blasone R, Gerdon F, Bach R, et al. Acceptability of app-based contact tracing for COVID-19: cross-country survey study. JMIR Mhealth Uhealth 2020 Aug 28;8(8):e19857 [FREE Full text] [doi: 10.2196/19857] [Medline: 32759102$]$

9. Bosshardt L, Bühler G, Craviolini J, Hermann M, Krähenbühl D. Federal Tracing App (Report in German). Zurich: Federal Office of Public Health; 2020 May 25. URL: https://www.newsd.admin.ch/newsd/message/attachments/61463.pdf [accessed 2021-01-28]

10. Key figures for the Corona-Warn-App (Article in German). Robert Koch Institute. 2020 Oct 30. URL: https://www.rki.de/ DE/Content/InfAZ/N/Neuartiges Coronavirus/WarnApp/Archiv Kennzahlen/Kennzahlen 30102020. pdf? blob=publicationFile [accessed 2020-11-04]

11. Partheymüller J, Kritzinger S, Song H, Plescia C. Learn from South Korea? For the use and acceptance of the "Stop Corona" app in Austria (Article in German). University of Vienna - Corona Blog 31. 2020 May 06. URL: https://viecer.univie.ac.at/ corona-blog/corona-blog-beitraege/blog31/ [accessed 2021-01-11]

12. Kittel B, Kritzinger S, Boomgaarden H, Prainsack B, Eberl J, Kalleitner F, et al. The Austrian Corona Panel Project: monitoring individual and societal dynamics amidst the COVID-19 crisis. SSRN Journal. Preprint posted online on July 23, 20202020 [FREE Full text] [doi: 10.2139/ssrn.3654139]

13. Aichholzer J, Kalleitner F. "Stop Corona” app: development in use and acceptance (Article in German). University of Vienna - Corona Blog. 2020 Nov 13. URL: https://viecer.univie.ac.at/corona-blog/corona-blog-beitraege/corona-dynamiken9/ [accessed 2021-01-11]

14. Hinch R, Probert W, Nurtay A, Kendall M, Wymant C, Hall M, et al. Effective Configurations of a Digital Contact Tracing App: A report to NHSX. 2020 Apr 16. URL: https://cdn.theconversation.com/static files/files/1009/ Report - Effective App Configurations.pdf?1587531217 [accessed 2021-02-02]

15. Hernández-Orallo E, Calafate CT, Cano J, Manzoni P. Evaluating the effectiveness of COVID-19 Bluetooth-based smartphone contact tracing applications. Applied Sciences 2020 Oct 13;10(20):7113. [doi: 10.3390/app10207113]

16. Salathé M, Althaus C, Anderegg N, Antonioli D, Ballouz T, Bugnon E, et al. Early evidence of effectiveness of digital contact tracing for SARS-CoV-2 in Switzerland. Swiss Med Wkly 2020 Dec 14;150:w20457 [FREE Full text] [doi: 10.4414/smw.2020.20457] [Medline: $\underline{33327003}$ ]

17. Maccari L, Cagno V. Do we need a contact tracing app? Comput Commun 2021 Jan 15;166:9-18 [FREE Full text] [doi: 10.1016/j.comcom.2020.11.007] [Medline: 33235399]

18. Rowe F, Ngwenyama O, Richet J. Contact-tracing apps and alienation in the age of COVID-19. European Journal of Information Systems 2020 Sep 13;29(5):545-562. [doi: 10.1080/0960085x.2020.1803155] 
19. Mbunge E. Integrating emerging technologies into COVID-19 contact tracing: opportunities, challenges and pitfalls. Diabetes Metab Syndr 2020;14(6):1631-1636. [doi: 10.1016/j.dsx.2020.08.029] [Medline: 32892060]

20. Vo V, Auroy L, Sarradon-Eck A. Patients' perceptions of mHealth apps: meta-ethnographic review of qualitative studies. JMIR Mhealth Uhealth 2019 Jul 10;7(7):e13817 [FREE Full text] [doi: 10.2196/13817] [Medline: 31293246]

21. Payne HE, Lister C, West JH, Bernhardt JM. Behavioral functionality of mobile apps in health interventions: a systematic review of the literature. JMIR mHealth uHealth 2015 Feb 26;3(1):e20 [FREE Full text] [doi: 10.2196/mhealth.3335] [Medline: 25803705]

22. Birkhoff SD, Smeltzer SC. Perceptions of smartphone user-centered mobile health tracking apps across various chronic illness populations: an integrative review. J Nurs Scholarsh 2017 Jul;49(4):371-378. [doi: 10.1111/jnu.12298] [Medline: 28605151]

23. Deng Z, Mo X, Liu S. Comparison of the middle-aged and older users' adoption of mobile health services in China. Int J Med Inform 2014 Mar;83(3):210-224. [doi: 10.1016/j.ijmedinf.2013.12.002] [Medline: 24388129]

24. Peng W, Kanthawala S, Yuan S, Hussain SA. A qualitative study of user perceptions of mobile health apps. BMC Public Health 2016 Nov 14;16(1):1158 [FREE Full text] [doi: 10.1186/s12889-016-3808-0] [Medline: 27842533]

25. Kwon M, Mun K, Lee JK, McLeod DM, D'Angelo J. Is mobile health all peer pressure? The influence of mass media exposure on the motivation to use mobile health apps. Convergence 2016 Apr 10;23(6):565-586. [doi: $10.1177 / 1354856516641065]$

26. Simblett S, Matcham F, Siddi S, Bulgari V, Barattieri di San Pietro C, Hortas López J, RADAR-CNS Consortium. Barriers to and facilitators of engagement with mHealth technology for remote measurement and management of depression: qualitative analysis. JMIR mHealth uHealth 2019 Jan 30;7(1):e11325 [FREE Full text] [doi: 10.2196/11325] [Medline: 30698535]

27. Spann A, Stewart E. Barriers and facilitators of older people's mHealth usage: a qualitative review of older people's views. Human Technology 2018 Nov 30:264-296. [doi: 10.17011/ht/urn.201811224834]

28. O'Connor S, Hanlon P, O'Donnell CA, Garcia S, Glanville J, Mair FS. Understanding factors affecting patient and public engagement and recruitment to digital health interventions: a systematic review of qualitative studies. BMC Med Inform Decis Mak 2016 Sep 15;16(1):120 [FREE Full text] [doi: 10.1186/s12911-016-0359-3] [Medline: 27630020]

29. Cajita MI, Hodgson NA, Lam KW, Yoo S, Han H. Facilitators of and barriers to mHealth adoption in older adults with heart failure. Comput Inform Nurs 2018 Aug;36(8):376-382 [FREE Full text] [doi: 10.1097/CIN.0000000000000442] [Medline: 29742549]

30. Stach M, Kraft R, Probst T, Messner EM, Terhorst Y, Baumeister H, et al. Mobile health app database - a repository for quality ratings of mHealth apps. : IEEE; 2020 Presented at: IEEE 33rd International Symposium on Computer-Based Medical Systems (CBMS); July 28-30, 2020; Rochester, MN p. 427-432. [doi: 10.1109/CBMS49503.2020.00087]

31. Korpershoek YJG, Vervoort SCJM, Trappenburg JCA, Schuurmans MJ. Perceptions of patients with chronic obstructive pulmonary disease and their health care providers towards using mHealth for self-management of exacerbations: a qualitative study. BMC Health Serv Res 2018 Oct 04;18(1):757 [FREE Full text] [doi: 10.1186/s12913-018-3545-4] [Medline: 30286761]

32. Sheats JL, Petrin C, Darensbourg RM, Wheeler CS. A Theoretically-Grounded Investigation of Perceptions About Healthy Eating and mHealth Support Among African American Men and Women in New Orleans, Louisiana. Fam Community Health 2018;41 Suppl 2 Suppl, Food Insecurity and Obesity:S15-S24 [FREE Full text] [doi: 10.1097/FCH.0000000000000177] [Medline: 29461312]

33. Dallinga J, Janssen M, van der Werf J, Walravens R, Vos S, Deutekom M. Analysis of the Features Important for the Effectiveness of Physical Activity-Related Apps for Recreational Sports: Expert Panel Approach. JMIR Mhealth Uhealth 2018 Jun 18;6(6):e143 [FREE Full text] [doi: 10.2196/mhealth.9459] [Medline: 29914863]

34. Trang S, Trenz M, Weiger W, Tarafdar M, Cheung C. One app to trace them all? Examining app specifications for mass acceptance of contact-tracing apps. European Journal of Information Systems 2020 Jul 27;29(4):415-428. [doi: 10.1080/0960085X.2020.1784046]

35. Guillon M, Kergall P. Attitudes and opinions on quarantine and support for a contact-tracing application in France during the COVID-19 outbreak. Public Health 2020 Nov;188:21-31 [FREE Full text] [doi: 10.1016/j.puhe.2020.08.026] [Medline: 33059232]

36. Joo J, Shin M. Resolving the tension between full utilization of contact tracing app services and user stress as an effort to control the COVID-19 pandemic. Serv Bus 2020 Sep 01;14(4):461-478 [FREE Full text] [doi: 10.1007/s11628-020-00424-7] [Medline: 18300068$]$

37. O'Callaghan ME, Buckley J, Fitzgerald B, Johnson K, Laffey J, McNicholas B, et al. A national survey of attitudes to COVID-19 digital contact tracing in the Republic of Ireland. Ir J Med Sci 2020 Oct 16 [FREE Full text] [doi: 10.1007/s11845-020-02389-y] [Medline: 33063226]

38. Sharma S, Singh G, Sharma R, Jones P, Kraus S, Dwivedi Y. Digital Health Innovation: Exploring Adoption of COVID-19 Digital Contact Tracing Apps. IEEE Trans. Eng. Manage 2004:1-17. [doi: 10.1109/TEM.2020.3019033] 
39. Walrave M, Waeterloos C, Ponnet K. Ready or Not for Contact Tracing? Investigating the Adoption Intention of COVID-19 Contact-Tracing Technology Using an Extended Unified Theory of Acceptance and Use of Technology Model. Cyberpsychol Behav Soc Netw 2020 Oct 05. [doi: 10.1089/cyber.2020.0483] [Medline: 33017171]

40. Kaspar K. Motivations for social distancing and app use as complementary measures to combat the COVID-19 pandemic: quantitative survey study. J Med Internet Res 2020 Aug 27;22(8):e21613 [FREE Full text] [doi: 10.2196/21613] [Medline: $\underline{32759100]}$

41. Keshet Y. Fear of panoptic surveillance: using digital technology to control the COVID-19 epidemic. Isr J Health Policy Res 2020 Nov 25;9(1):67 [FREE Full text] [doi: 10.1186/s13584-020-00429-7] [Medline: 33239094]

42. Eck K, Hatz S. State surveillance and the COVID-19 crisis. Journal of Human Rights 2020 Nov 11;19(5):603-612 [FREE Full text] [doi: 10.1080/14754835.2020.1816163] [Medline: 32836636]

43. Fahey RA, Hino A. COVID-19, digital privacy, and the social limits on data-focused public health responses. Int J Inf Manage 2020 Dec;55:102181 [FREE Full text] [doi: 10.1016/j.ijinfomgt.2020.102181] [Medline: $\underline{32836638}$ ]

44. Zhang M, Chow A, Smith H. COVID-19 Contact-Tracing Apps: Analysis of the Readability of Privacy Policies. J Med Internet Res 2020 Dec 03;22(12):e21572 [FREE Full text] [doi: 10.2196/21572] [Medline: $\underline{33170798]}$

45. Sunyaev A, Dehling T, Taylor PL, Mandl KD. Availability and quality of mobile health app privacy policies. J Am Med Inform Assoc 2015 Apr;22(e1):e28-e33. [doi: 10.1136/amiajnl-2013-002605] [Medline: 25147247]

46. Nikolaou CK, Tay Z, Leu J, Rebello SA, Te Morenga L, Van Dam RM, et al. Young People's Attitudes and Motivations Toward Social Media and Mobile Apps for Weight Control: Mixed Methods Study. JMIR Mhealth Uhealth 2019 Oct 10;7(10):e11205 [FREE Full text] [doi: 10.2196/11205] [Medline: 31603431]

47. Willcox JC, van der Pligt P, Ball K, Wilkinson SA, Lappas M, McCarthy EA, et al. Views of Women and Health Professionals on mHealth Lifestyle Interventions in Pregnancy: A Qualitative Investigation. JMIR Mhealth Uhealth 2015 Oct 28;3(4):e99 [FREE Full text] [doi: 10.2196/mhealth.4869] [Medline: 26510886]

48. Alexopoulos AR, Hudson JG, Otenigbagbe O. The Use of Digital Applications and COVID-19. Community Ment Health J 2020 Oct;56(7):1202-1203 [FREE Full text] [doi: 10.1007/s10597-020-00689-2] [Medline: 32734311]

49. Soroya SH, Farooq A, Mahmood K, Isoaho J, Zara S. From information seeking to information avoidance: Understanding the health information behavior during a global health crisis. Inf Process Manag 2021 Mar;58(2):102440 [FREE Full text] [doi: 10.1016/j.ipm.2020.102440] [Medline: 33281273]

50. Basch CH, Kecojevic A, Wagner VH. Coverage of the COVID-19 pandemic in the online versions of highly circulated U.S. daily newspapers. J Community Health 2020 Dec;45(6):1089-1097 [FREE Full text] [doi: 10.1007/s10900-020-00913-w] [Medline: $\underline{\text { 32902813] }}$

51. Zimmermann BM, Aebi N, Kolb S, Shaw D, Elger BS. Content, evaluations and influences in newspaper coverage of predictive genetic testing: A comparative media content analysis from the United Kingdom and Switzerland. Public Underst Sci 2019 Apr;28(3):256-274. [doi: 10.1177/0963662518816014] [Medline: 30583711]

52. Donelle L, Hoffman-Goetz L, Clarke JN. Ethnicity, genetics, and breast cancer: media portrayal of disease identities. Ethn Health 2005 Aug;10(3):185-197. [doi: 10.1080/13557850500120751] [Medline: 16087452]

53. Niederdeppe J, Frosch DL, Hornik RC. Cancer news coverage and information seeking. J Health Commun 2008 Mar;13(2):181-199 [FREE Full text] [doi: 10.1080/10810730701854110] [Medline: 18300068]

54. Pierce JP, Gilpin EA. News media coverage of smoking and health is associated with changes in population rates of smoking cessation but not initiation. Tob Control 2001 Jun;10(2):145-153 [FREE Full text] [doi: 10.1136/tc.10.2.145] [Medline: 11387535]

55. Wirth W, Kolb S. Designs and methods of comparative political communication research. In: Esser F, Pfetsch B, editors. Comparing Political Communication: Theories, Cases, and Challenges (Communication, Society and Politics). Cambridge: Cambridge University Press; 2004:87-112.

56. Solidarity in times of a pandemic: What do people do, and why? University of Vienna - Research Platform: Governance of digital practices. URL: https://digigov.univie.ac.at/solidarity-in-times-of-a-pandemic-solpan/ [accessed 2021-01-11]

57. Wirth W, Kolb S. Securing equivalence: problems and solutions. In: Esser F, Hanitzsch T, editors. The Handbook of Comparative Communication Research (1st Edition). Abingdon: Routledge; Mar 2012:469-485.

58. Su Y, Borah P. Who is the agenda setter? Examining the intermedia agenda-setting effect between Twitter and newspapers. Journal of Information Technology \& Politics 2019 Jul 13;16(3):236-249. [doi: 10.1080/19331681.2019.1641451]

59. Dow Jones Professional. URL: https://professional.dowjones.com/factiva/ [accessed 2021-02-02]

60. Rowe F. Contact tracing apps and values dilemmas: A privacy paradox in a neo-liberal world. Int J Inf Manage 2020 Dec;55:102178 [FREE Full text] [doi: 10.1016/j.ijinfomgt.2020.102178] [Medline: 32836636]

61. Bengio Y, Janda R, Yu YW, Ippolito D, Jarvie M, Pilat D, et al. The need for privacy with public digital contact tracing during the COVID-19 pandemic. Lancet Digit Health 2020 Jul;2(7):e342-e344 [FREE Full text] [doi: 10.1016/S2589-7500(20)30133-3] [Medline: 32835192]

62. Loi M. How to fairly incentivise digital contact tracing. J Med Ethics $2020 \mathrm{Jul} 09$ [FREE Full text] [doi: 10.1136/medethics-2020-106388] [Medline: 32647047]

63. Siffels LE. Beyond privacy vs. health: a justification analysis of the contact-tracing apps debate in the Netherlands. Ethics Inf Technol 2020 Oct 10:1-5 [FREE Full text] [doi: 10.1007/s10676-020-09555-x] [Medline: 33071607] 
64. Martinez-Martin N, Wieten S, Magnus D, Cho MK. Digital contact tracing, privacy, and public health. Hastings Cent Rep 2020 May;50(3):43-46 [FREE Full text] [doi: 10.1002/hast.1131] [Medline: 32596893]

65. Hendl T, Chung R, Wild V. Pandemic surveillance and racialized subpopulations: mitigating vulnerabilities in COVID-19 apps. J Bioeth Inq 2020 Dec;17(4):829-834 [FREE Full text] [doi: 10.1007/s11673-020-10034-7] [Medline: 32840858]

66. Klenk M, Duijf H. Ethics of digital contact tracing and COVID-19: who is (not) free to go? Ethics Inf Technol 2020 Aug 24:1-9 [FREE Full text] [doi: 10.1007/s10676-020-09544-0] [Medline: 32863740]

67. Sharon T. Blind-sided by privacy? Digital contact tracing, the Apple/Google API and big tech's newfound role as global health policy makers. Ethics Inf Technol 2020 Jul 18:1-13 [FREE Full text] [doi: 10.1007/s10676-020-09547-x] [Medline: 32837287]

68. Kalleitner F, Pollak M, Partheymueller J. High approval of the mask requirement: $81 \%$ think that it should apply (Article in German). University of Vienna - Corona Blog. 2020 Sep 28. URL: https://viecer.univie.ac.at/corona-blog/ corona-blog-beitraege/corona-dynamiken2/ [accessed 2021-01-11]

69. Betsch C, Korn L, Sprengholz P, Felgendreff L, Eitze S, Schmid P, et al. Social and behavioral consequences of mask policies during the COVID-19 pandemic. Proc Natl Acad Sci U S A 2020 Sep 08;117(36):21851-21853 [FREE Full text] [doi: 10.1073/pnas.2011674117] [Medline: 32820078]

70. Voigt TH, Holtz V, Niemiec E, Howard HC, Middleton A, Prainsack B. Willingness to donate genomic and other medical data: results from Germany. Eur J Hum Genet 2020 Aug;28(8):1000-1009 [FREE Full text] [doi: 10.1038/s41431-020-0611-2] [Medline: $\underline{32238912]}$

71. Marikyan D, Papagiannidis S, Alamanos E. Cognitive dissonance in technology adoption: a study of smart home users. Inf Syst Front 2020 Jul 25:1-23 [ $\underline{\text { FREE Full text] [doi: } 10.1007 / \mathrm{s} 10796-020-10042-3]}$ [Medline: $\underline{32837263}$ ]

72. Barth S, de Jong MD. The privacy paradox - Investigating discrepancies between expressed privacy concerns and actual online behavior - a systematic literature review. Telematics and Informatics 2017 Nov;34(7):1038-1058. [doi: 10.1016/j.tele.2017.04.013]

73. Ranisch R, Nijsingh N, Ballantyne A, van Bergen A, Buyx A, Friedrich O, et al. Digital contact tracing and exposure notification: ethical guidance for trustworthy pandemic management. Ethics Inf Technol 2020 Oct 21:1-10 [FREE Full text] [doi: 10.1007/s10676-020-09566-8] [Medline: $\underline{33106749]}$

74. The app credibility gap. Nat Biotechnol 2020 Jul;38(7):768 [FREE Full text] [doi: 10.1038/s41587-020-0610-4] [Medline: 32591763]

75. Parker MJ, Fraser C, Abeler-Dörner L, Bonsall D. Ethics of instantaneous contact tracing using mobile phone apps in the control of the COVID-19 pandemic. J Med Ethics 2020 Jul;46(7):427-431 [FREE Full text] [doi: 10.1136/medethics-2020-106314] [Medline: 32366705]

76. Coghlan S, Cheong M, Coghlan B. Tracking, tracing, trust: contemplating mitigating the impact of COVID-19 through technological interventions. Med J Aust 2020 Jul;213(2):94-94.e1 [FREE Full text] [doi: 10.5694/mja2.50680] [Medline: 32570292]

77. Lucivero F, Hallowell N, Johnson S, Prainsack B, Samuel G, Sharon T. COVID-19 and contact tracing apps: ethical challenges for a social experiment on a global scale. J Bioeth Inq 2020 Dec;17(4):835-839 [FREE Full text] [doi: 10.1007/s11673-020-10016-9] [Medline: 32840842]

78. Low J. A pragmatic definition of the concept of theoretical saturation. Sociological Focus 2019 Jan 27;52(2):131-139. [doi: $10.1080 / 00380237.2018 .1544514]$

79. Deopa N, Forunato P. Coronagraben. Culture and social distancing in times of COVID-19. SSRN Journal. Preprint posted online on Jun 29, 2020 2020. [doi: 10.2139/ssrn.3635287]

\section{Abbreviations \\ DP-3T: Decentralized Privacy-Preserving Proximity Tracing \\ mHealth: mobile health \\ PEPP-PT: Pan-European Privacy-Preserving Proximity Tracing \\ SolPan: Solidarity in Times of a Pandemic}

Edited by G Eysenbach; submitted 05.11.20; peer-reviewed by F Rowe, A Chang, M Ariyan, Z Aghaei, A Khaleghi; comments to author 02.12.20; revised version received 17.12.20; accepted 09.01.21; published 08.02.21

Please cite as:

Zimmermann BM, Fiske A, Prainsack B, Hangel N, McLennan S, Buyx A

Early Perceptions of COVID-19 Contact Tracing Apps in German-Speaking Countries: Comparative Mixed Methods Study

J Med Internet Res 2021;23(2):e25525

URL: http://www.jmir.org/2021/2/e25525/

doi: $\underline{10.2196 / 25525}$

PMID: $\underline{33503000}$ 
CBettina Maria Zimmermann, Amelia Fiske, Barbara Prainsack, Nora Hangel, Stuart McLennan, Alena Buyx. Originally published in the Journal of Medical Internet Research (http://www.jmir.org), 08.02.2021. This is an open-access article distributed under the terms of the Creative Commons Attribution License (https://creativecommons.org/licenses/by/4.0/), which permits unrestricted use, distribution, and reproduction in any medium, provided the original work, first published in the Journal of Medical Internet Research, is properly cited. The complete bibliographic information, a link to the original publication on http://www.jmir.org/, as well as this copyright and license information must be included. 